\title{
The Effect of Social Learning-Related Variables on Academic Achievement
}

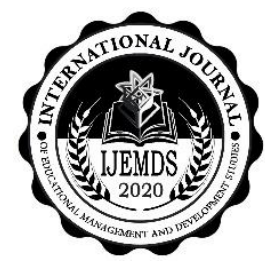

\author{
Edilberto A. Magsino Jr.
}

\begin{abstract}
This study determined the relationship between the social learning-related variables and the skills achievement in Mathematics of the 200 Grade 8 students in a public school in the Philippines. Descriptive research design was used through a self-constructed questionnaire and an assessment test. The data gathered were presented in a tabular mean while the relationship between variables was tested using Pearson $\mathrm{r}$ correlation coefficient. The students' social learning-related variables were highly manifested (WAM = 3.44, SD = 1.11). However, only $11.5 \%$ of the students have satisfactory performance in Mathematics. Among the demographic profile, only mothers' educational attainment has shown significant relationship with mathematics achievement in terms of estimation $(r=0.184)$. Among the social learning-related variables, attitude of the students indicated significant relationship with both estimation $(r=0.184)$ and problem solving $(r=0.196)$. Peer support also revealed significant relationship with both representation $(r=0.167)$ and estimation $(r=0.159)$. The mathematics teacher must find effective ways on how to overcome the students' difficulties and thus develop their mathematical skills. Efforts to thresh out problems in vocabulary development especially solving worded problems may be exerted. A parallel study may be conducted using variables not considered in this research.
\end{abstract}

Keywords:

mathematics, social learning-related variables, academic achievement, effect on academic achievement

Suggested Citation: Magsino, E.A. (2021). The Effect of Social Learning-Related Variables on Academic Achievement in Mathematics. International Journal of Educational Management and Development Studies, Volume 2, Issue 2, pp. 75 - 92.

\section{About the author:}

Teacher. Dolores Macasaet National High School, Philippines 


\section{Introduction}

In one of the reports in the World Economic Forum, de Leon (2011) cited that in the recent results of international studies, the Philippines was second least among the eight ASEAN countries in terms of students' performance in mathematics, science, innovation, and education. Similarly, the Philippines was 99th out of 138 countries in the basic education. The country also ranked 69th on the world educational system, 112th in Science and Math, and 76th on online usage. In general, the Philippines is lagging behind its regional neighbors in terms of education and academic performance (Kolar, et al, 2012).

This scenario of the country's performance calls for attention to improve the teaching and learning in all the levels of education. There are so many factors associated with the poor performance in mathematics but a number of researchers commonly agree on the students' attitude towards mathematics (Makondo \& Makondo, 2020; Chand, et al., 2021; Michael, 2015; Sanchal \& Sharma, 2017). This attitude constitutes cognitive, affective and behavioural reactions (Han \& Carpenter, 2014). According to Davadas and Lay (2017), students' attitude is affected by such other factors as parental influences, teacher affective support and classroom instruction. Ayob and Yasin (2017) also consider opportunity to learn and teaching practice as contribution factors. Although there are several factors affecting the poor performance of students in mathematics, the students' characteristics and the influence of the people around them are dominant predictors.

Considering the various factors affecting academic performance in mathematics, this study identified the social learning-related variables, indicators of students' qualities and the people around them. It assessed the social learning-related variables such as study habits, attitude, interest and motivation in terms of parental guidance, peer support and teacher support in order to determine any significant relationship with the achievement level of students in number sentence, representation, spatial sense, measurement, estimation and problem solving.

The following are the hypotheses of the study:

HO1: There is no significant relationship between the social learningrelated variables and students' academic achievement in mathematics.

HO2: There is no significant relationship between the students' demographic profile and academic achievement in mathematics. 


\section{Literature review}

The learner's school achievement and performance is a primary gauge of a society's efficient education status both in the developed and developing countries. As such, international assessments and evaluation of the academic index largely affects the policies and decisions of countries around the world to further enhance their communities and to achieve their collective goals (Yalcin, 2017). Thus, the existence of the regular national achievement tests, and other international standardized evaluations such as the Programme for International Student Assessment (PISA) and the Trends in International Mathematics and Science Study (TIMSS).

There are numerous social learning variables identified that affect students' performance in mathematics. For instance, the effects of age on various outcomes such as academic achievement or earned wages have been addressed in many studies in education and economic research. Most of the studies analyzing achievement and relative age effects at the beginning of formal schooling have found that relatively older students perform better academically than relatively younger students (Small, 2015). Person related factors such as age and gender have been linked to affect the Mathematical achievement of students. Ganly and Lubienzki (2016) stressed that gender differences on Mathematics tests tend to be more pronounced when the content of the assessment is less related to the material that is taught in school (for example, on the SAT- Mathematics as opposed to a Mathematics test in school). In addition, researchers consistently find that gender gaps are larger among higherperforming students, which may partially explain why we see gender gaps in Mathematicsrelated careers, as these are often pursued by the highest-performing students (Ganly and Lubienzki, 2016).

Several studies proved relationship between gender and mathematics achievement. For instance, Recber, Isiksal, and Koc (2018) found that gender is a key factor and has a significant relationship to Mathematical self-efficacy, anxiety, and attitudes among the seventh grade learners. Similarly, Hannula (2012) noted that the Finish senior high school students' Mathematical satisfaction is primarily affected by gender, and that their perceived competence is related to their Mathematical performance. This was also elaborated by Watt (2005) that the performance in Mathematics can be associated with their ability to process 
critical problem solving skills in the context of their education, occupation, and personal choice. However, Mutai (2016) found that girls had formed negative attitudes towards the subject while boys have a positive attitude towards learning of Mathematics.

Attitudes and values also affect the Mathematical achievement since age and gender also affect those variables. Research consistently shows that, even from a fairly young age, girls are less confident and more anxious about Mathematics than boys. Moreover, these differences in confidence and anxiety are larger than actual gender differences in Mathematics achievement. For example, researchers have found that boys tend to use more novel problem-solving strategies, whereas girls are more likely to follow school-taught procedures. Moreover, Brown and Kanyongo (2018) found in their study that girls performed better than boys on all categories and all skill areas on the test, the effect sizes were small. The results of a follow-up descriptive discriminant analysis also indicate that while boys and girls did not differ with regard to the perception of the school environment, educational values and goals, and general academic self-concept, they differ significantly on the persistence and Mathematics self-concept factors. Girls tend to persist more, but hold lower Mathematics self-concept than boys.

Another factor is socio-economic background which is relative standing of a family in a society based on its income, power, background and prestige (Gouc, 2013; Illiyas, 2017). It includes family socio-economic background includes family income, standard of house occupied or rented, family size, parental education and level of family stability among other factors (Ovute, (2012). The socio-economic status of a parent goes a long way to mold a child's personality both morally, academically, economically, socially, spiritually or otherwise (Eccles \& Daviskean, 2015). In addition, Iruka and Barbain (2008) stated that parents and guardians are the primary influence especially during the early part of their development. Such influence may result to a particular stress in their residence (Cross, Woods, \& Schweingruber, 2009). Friedel, Cortino, Turner, and Midgley (2010) argued that parents' interaction and influence in different ways is a key measurement for developing children's Mathematical engagement. Recent studies have shown that some clear factors that affect and link the primary role in creating and influencing Mathematical performance of children are as follows - parental vision, family communication, the family organization, and parental support in the children's academic involvement (Wang, 2004). Bicer, Capraro, and 
Capraro (2013) also found that parents with above-average educational profile is prone to set a higher expectation to their children which provides positive reinforcement to their children (Hong, You, \& Wu, 2010) transmitted and demonstrated during the parent-children interaction (Demir, Kilic, \&Unal, 2010; Fox \& Larke, 2014). This was further supported by the study of Wang and Li (2014) that several important constituents of SES, such as parents' education and family income have influence on the mathematics achievement of the Chinese students which suggest that low SES has a significant negative relationship with Mathematics achievement (Hernandez, 2014; Qiang Cheng \& Hsien-Yuan Hsu, 2016) .

On parental guidance and support, Nyabuto (2014) mentioned that students whose parents are involved in their education are more likely to perform better in Mathematics and achieve more than other students. The parents' contribution to their children's education has a consistent and positive effect on the self-concept of elementary students (Chohan, 2010) and academic achievement of the primary school pupils (Fajoju, Aluede, \& Ojugo, (2015).

The learners' nature and their environment also play a crucial role in the academic achievement. The nature of learners - their inner motivation, personality, character, expectations, and aspirations integrates dynamically to their environment. The students' environment not only refers to their immediate classroom and social groups, but extends more to their school, family, and all the way to the community (Visser \& Fezza, 2015). It is also a predictor of self-efficacy and achievement (Bitar \& Zedan, 2014). However, Blazar and Kraft (2017) found that upper-elementary teachers have large effects on self-reported measures of students' self-efficacy in Mathematics, and happiness and behavior in class.

The attitude towards mathematics and study habits also have strong impact on the academic performance. Sakirudeen and Sanni (2017) found a significant relationship between note taking, students' use of library, time allocation for study and students' academic performance in Mathematics. Meanwhile, Um (2017) added that intrinsic motivation positively affects whereas external regulation negatively affects Mathematics performance. There was also significant positive correlations between internal motivation and self-reported Mathematics grades, self-reported grades and enjoyment, and self-reported grades and confidence (Herges, Duffield, Martin \& Wageman, 2017). Similarly, Odiri (2015) found significant relationship between study habits and Mathematics achievement and there was a 
significant difference in Mathematics achievement between good study habits and poor study habits of secondary students in Nigeria. There is also positive relations between achievement and self-efficacy (Saileela, 2012; Yara, 2014; Heinze, 2014; Sekhar \& Karanam, 2014; Tudy, 2014) and achievement and student attitude (Yara, 2012; Mata, Monteiro \& Peixata, 2012; Vardardottir, 2012; Adeyinka, 2013; Hernandez, 2014).

\section{Methodology}

This study used the descriptive correlation research design. Demographic variables and other social learning-related variables were tested for statistical relation with the achievement in mathematics.

A pre-tested questionnaire consisting of two parts was used. The first part describes the profile of the students such as age, gender and their parents' educational attainment, occupation and monthly income. The second part covered relevant social variables such as study habits, attitude, interest and motivation, which include parental guidance, peer support and teachers' support. This part used the five-point Likert scale. In addition, a selfconstructed achievement test, which was referred to the classroom teachers for validation, was also used. This 60-point examination aims to measure the skills of the students in number sentence, representation, spatial sense, measurement, estimation, and problem solving. Each item for the mathematical skill is given one point except for representation and problem solving with two points each. The test scores were the indicator of skills achievement in mathematics.

The respondents of the study consisted of 200 Grade 8 students in one of the public high schools in Quezon Province during the school year 2018-2019. The sample size comprises $94 \%$ of the total students in the six (6) classes. Purposive sampling procedure was utilized in the study. The demographic profile of the students showed that majority of student-respondents are in the age bracket 14-15 (53\%), majority are female (57\%), whose fathers and mothers are mostly high school graduates (29\% \& 32\%, respectively), with combined family income of P 5, 000.00 and below (47\%).

The researcher asked permission from the school head in the research locale to conduct the study among the Grade 8 students. The researcher also asked permission for the 
involvement of other Mathematics and English teachers in validating the tests for assessing the performance of the students' respondents. The researcher conducted the survey and assessment test personally.

The statistical treatments used were frequency count, percent distribution, mean, standard deviation and Pearson - Product Moment Coefficient at the .05 level of significance.

\section{Findings and Discussion}

\section{Table 1}

\section{The Perceived Social Learning-Related Variables}

\begin{tabular}{lllc}
\hline Indicators & WAM & SD & Interpretation \\
Study habits & 3.27 & 1.11 & Moderately manifested \\
Attitude & 3.65 & 1.06 & Highly manifested \\
Interest & 2.88 & 1.21 & Moderately manifested \\
Parental Guidance & 3.64 & 1.10 & Highly manifested \\
Peer Support & 3.48 & 1.09 & Highly manifested \\
Teacher Support & 3.69 & 1.07 & Highly manifested \\
Overall & $\mathbf{3 . 4 4}$ & $\mathbf{1 . 1 1}$ & Highly manifested \\
\hline $\begin{array}{l}\text { Legend: } N=200, \text { 1.0-1.80 (Not At All Manifested), } 1.81-2.60 \text { (Slightly Manifested), 2.61-3.40 (Moderately manifested), 3.41- } \\
\text { 4.20 (Highly Manifested), 4.21-5.0 (Very Highly Manifested) }\end{array}$ & &
\end{tabular}

The summary on perceived social learning-related variables is indicated in Table 1. The overall mean of 3.44 is interpreted as "highly manifested" with standard deviation of 1.11. The standard deviation suggests that there is homogeneity in the students' perception on the social learning-related variables. Results indicate that the students perceived social learning-related variables as may have influenced mathematics are highly manifested. The highest mean obtained is on teacher support (3.69) with standard deviation of 1.07, which is 'Highly Manifested' while lowest mean gathered is on interest (2.88) with standard deviation of 1.21 interpreted as "moderately manifested".

In terms of the study habits, students have high regards to asking for help on confusing ideas or lesson in Mathematics (WAM $=3.52, \mathrm{SD}=1.13$ ) while low regards to 
studying and practicing mathematics drills during free time (WAM $=3.09, \mathrm{SD}=0.95)$. The overall mean of 3.27 reveals that the students "sometimes practiced" their study habits. As noted by Sakirudeen and Sanni (2017) that these habits have significant relationship with the academic performance. However, results indicate that students need to improve their study habits in order to improve their academic performance in mathematics.

Meanwhile, the attitude of the students show high respect for teachers and classmates (WAM $=4.60, \mathrm{SD}=0.08$ ). However, they may have issue with the Mathematics textbooks and other learning resources in school and at home (WAM $=3.2, \mathrm{SD}=1.02$ ). This supports the study of Yara (2014) showing that students' attitudes towards Mathematics were positive and that many of them believed that Mathematics is a worthwhile and necessary subject, which can help them in their future career.

The interest of the students was reflected by their perception that "numbers appear the least" (WAM $=3.32, \mathrm{SD}=1.14)$ as the highest and that "mathematics book does not interest them" (WAM = 2.44, SD = 1.24). As explained by Heinze (2014) that interest could be regarded as a predictor for Mathematics achievement. The results indicated that students are uncertain as to whether their interest is a variable to learning skill development probably because they have not fully acquired the needed competencies and skills in the four fundamental operations.

The students generally "agree" that parental guidance is indeed a variable in skills development as shown by their highest regards to parental support in studies (WAM $=4.4$, $\mathrm{SD}=0.78$ ) which was verified by lowest assessment on the statement "My parents cannot afford to support my studies" (WAM $=2.55, \mathrm{SD}=1.34$ ). The overall standard deviation of 1.10 indicates homogeneity in students' perception. It implies that students perceive parental guidance as very important in developing skills in solving Mathematical problems that supports Nyabuto (2014). The parental involvement directly affects their children's Mathematics achievement. Students whose parents are involved in their education are more likely to perform better in Mathematics and achieve more than other students.

The students' perception of peer support was also positive. Among the indicators, the item "My friends motivate me to study well." has the highest mean of 4.04 but the item "My friends give me money to support my studies" has the lowest mean of 2.15. The value of peer support as mentioned by Vardardottir (2012) was clearly reflected in the results. The peer 
effects and academic achievement are two interrelated variables. It clearly shows that peers have strong influence on the habits and performance of the students.

Lastly, the students generally "agree" that teacher support is indeed a variable in skills development. "My teachers give me advice regarding Mathematics." and "My teachers encourage me to learn." are indicators with both the highest mean with 4.13 and standard deviations of 0.95 and 1.07, respectively. In addition, teachers give students' money (WAM $=2.03, \mathrm{SD}=1.22$ ) was the least rated. This supports the claims of Adeyinka (2013) that the negative performance of student towards educational aims and objectives could be associated to the low moral support of teachers most especially in the area of Mathematics. The students' high regard to their teachers inspires them to achieve more in the class.

\section{Table 2}

\section{The Achievement Level of Students in Mathematics Skills}

The mathematical skills assessed were number sentence, representation, spatial sense, measurement, estimation, and problem solving. Table 2 presents the distribution of respondents through Mathematics skills test. The results reveal that most of the respondents'

\begin{tabular}{lccccccccccccc}
\hline Rating & \multicolumn{2}{c}{$\begin{array}{c}\text { Number } \\
\text { Sentence }\end{array}$} & \multicolumn{2}{c}{$\begin{array}{c}\text { Representati } \\
\text { on }\end{array}$} & \multicolumn{2}{c}{$\begin{array}{c}\text { Spatial } \\
\text { Sense }\end{array}$} & \multicolumn{2}{c}{$\begin{array}{c}\text { Measureme } \\
\text { nt }\end{array}$} & \multicolumn{2}{c}{$\begin{array}{c}\text { Estimation } \\
\text { Solving }\end{array}$} & \multicolumn{2}{c}{$\begin{array}{c}\text { Problem } \\
\text { Solving }\end{array}$} & Interpretation \\
& F & $\%$ & F & $\%$ & F & $\%$ & F & $\%$ & F & $\%$ & F & $\%$ & \\
\hline $\begin{array}{l}95 \text { and } \\
\text { above }\end{array}$ & 11 & 5.5 & 5 & 2.5 & 46 & 23 & 4 & 2 & 1 & 0.5 & 15 & 7.5 & Excellent \\
$88-94$ & 5 & 2.5 & 1 & 0.5 & 30 & 15 & 5 & 2.5 & 4 & 2 & 1 & 0.5 & Very \\
$82-87$ & 13 & 6.5 & 6 & 3 & 27 & 13.5 & 50 & 25 & 38 & 19 & 28 & 14 & Satisfactory \\
$76-81$ & 16 & 8 & 19 & 9.5 & 10 & 5 & 14 & 7 & 8 & 4 & 20 & 10 & Fair \\
$70-75$ & 155 & 77.5 & 169 & 84.5 & 87 & 43.5 & 127 & 63.5 & 149 & 74.5 & 136 & 68 & Poor \\
\hline
\end{tabular}

scores are within the range of 70 - 75 interpreted as "poor" in their performance. Only 21 or $10.5 \%$ of the respondents got scores within the 76 - 81 range interpreted as "fair". The students in this particular group still have the knowledge on how to convert length, mass/weight, capacity/volume and time to another unit even if they had taken the lessons for far too long before. Also, they are possibly interested in this part of the lesson.

A little less than $75 \%$, that is, $74.50 \%$ or 149 are "poor" in their performance. They got scores within the range of 70-75 since it has been observed that they know the lessons 
well when such were explained but when the test came, most of what had been taken were already forgotten. It implies then that there is still a need for some reinforcement and enrichment activities in Mathematics especially in measurement to overcome the difficulties of the students in order to improve their Mathematical skills. It is quite ironic to note that the students perception of the social learning variable are high but the test results show otherwise.

Table 3

Correlation between Mathematics Achievement and Social Learning-Related Variables

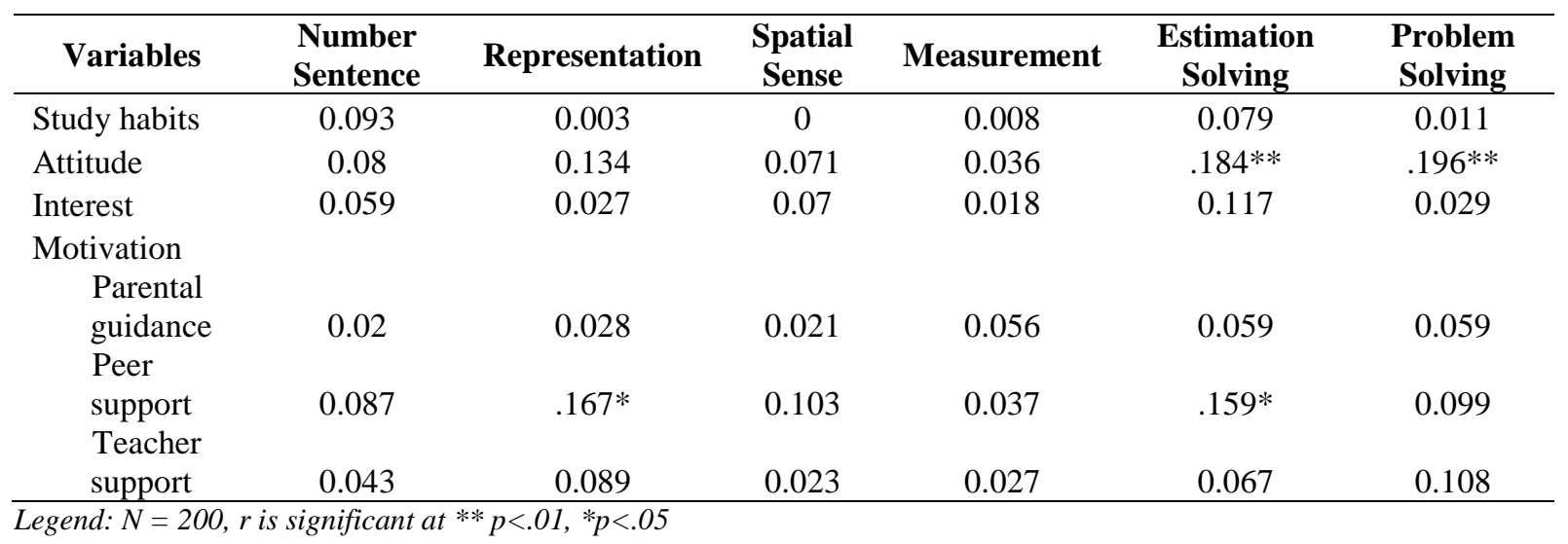

Table 3 shows the correlation between mathematics achievement in terms of number sentence, representation, spatial sense, measurement, estimation and problem solving and social learning-related variables such as study habits, attitude, interest, and motivation in terms of parental guidance, peer support and teachers' support.

Based on the statistical results, there is significant relationship between mathematical achievement and social learning-related variables such as: attitude and estimation $(r=0.184)$, attitude and problem solving $(\mathrm{r}=0.196)$, and peer support in terms of representation $(\mathrm{r}=$ $0.167)$ and estimation $(\mathrm{r}=0.159)$.

Findings indicated that if students have positive attitude towards mathematics. It is most likely that they will perform better in estimation and problem solving. Moreover, with enough and sufficient peer support, students will likely have better achievement in representation and estimation. These results affirm the study of Tudy (2014) and Yara (2012).

Table 4 
Correlation between Mathematics Achievement and Person-Related Factors

\begin{tabular}{lcccccc}
\hline \multicolumn{1}{c}{ Variables } & $\begin{array}{c}\text { Number } \\
\text { Sentence }\end{array}$ & Representation & $\begin{array}{c}\text { Spatial } \\
\text { Sense }\end{array}$ & Measurement & $\begin{array}{c}\text { Estimation } \\
\text { Solving }\end{array}$ & $\begin{array}{c}\text { Problem } \\
\text { Solving }\end{array}$ \\
\hline Age & 0.046 & 0.027 & 0.05 & 0.008 & 0.003 & 0.001 \\
$\begin{array}{l}\text { Gender } \\
\text { Father's educational } \\
\text { attainment }\end{array}$ & 0.04 & 0.048 & 0.034 & 0.051 & 0.062 & 0.019 \\
$\begin{array}{l}\text { Mother's educational } \\
\text { attainment }\end{array}$ & 0.021 & 0.011 & 0.051 & 0.001 & 0.109 & 0.079 \\
Father's occupation & 0.08 & 0.05 & 0.122 & 0.056 & $0.184 * *$ & 0.05 \\
$\begin{array}{l}\text { Mother's occupation } \\
\text { Parent's monthly }\end{array}$ & 0.016 & 0.088 & 0.065 & 0.001 & 0.049 & 0.036 \\
income & 0.078 & 0.023 & 0.002 & 0.095 & 0.098 & 0.012 \\
\hline Legend: $N=200$, r is significant at $* * p<.01, * 0<.05$ & 0.039 & 0.051 & 0.075 & 0.091 & 0.047 \\
\hline
\end{tabular}

Table 4 shows the correlation between Mathematical achievement in terms of number sentence, representation, spatial sense, measurement, estimation and problem solving and person - related factors such as age, gender, parents' educational attainment, parents' occupation, and parents' monthly income.

There is no correlation between mathematical achievement and person-related factors, except mother's educational attainment and estimation $(r=0.184)$. This implies that mother's educational attainment is significantly related to mathematics achievement in terms of estimation $(\mathrm{p}<0.01)$. This means that as educational attainment of mothers' decreases, the achievement level of the students in estimation also decreases and vice-versa. This confirms the studies of Eccles and Daviskean (2015), Friedel, Cortino, Turner and Midgley (2010), Bicer, Capraro, and Capraro (2013) and Hong, You and Wu (2010).

\section{Conclusion}

The study evaluated the social learning - related variables and Mathematics skills of the respondents to determine any significant relationship between these variables. The social learning - related variables were study habits, attitude, interest, parental guidance, peer support, and teacher support. The mathematics achievement was measured through a test on number sentence, representation, spatial sense, measurement, estimation and problem solving. The respondents of the study were the 200 Grade 8 students of a public school during the academic year 2018-2019. The study utilized descriptive research design using 
self-constructed questionnaires. The arithmetic mean and Pearson $r$ were the main statistical tools used.

The results showed that the students' social learning - related variables were highly manifested by the overall mean of 3.44 and standard deviation of 1.11 . However, only $11.5 \%$ of the student-respondents have at least satisfactory performance in Mathematics. The contrasting results of the two variables showed that only mothers' educational attainment has significant relationship with mathematics achievement in terms of estimation $(r=0.184)$. Furthermore, the attitude of the students indicated significant relationship with both estimation $(r=0.184)$ and problem solving $(r=0.196)$ while peer support has significant relationship with both representation $(r=0.167)$ and estimation $(r=0.159)$.

There is really an impending problem with the students' academic performance in mathematics. For this, the teacher may find other more effective ways on how to overcome the students' difficulties and thus develop their mathematics skills. Efforts to thresh out problems in vocabulary development especially solving worded-problems may be exerted. Coordination between teachers in English and teachers in Mathematics may be encouraged. Measures may be adopted to find out in what aspects students may be weak. Thus, greater emphasis may be placed in such aspects to upgrade their learning competency.

Classes for remediation maybe organized and the researcher's proposed learning plans may be used once approved by proper authorities. Teacher concerned may work with school administrators, or supervisors to look into or check the demands of the program. This might be especially on the provision of learning materials and facilities or devices. The attention of teachers of mathematics may focus on the students' difficulties resulting from detected variables as revealed by the findings in the study. A parallel study may be conducted using variables not considered in this research.

\section{APPENDICES}




\section{Appendix A}

\section{Perceived Social Learning - Related Variables as to Study Habits}

\begin{tabular}{lccc}
\hline \multicolumn{1}{c}{ Indicators } & M & SD & Interpretation \\
\hline $\begin{array}{l}\text { 1. Reading notes after class is included in my regular routine. } \\
\text { 2. Playing any games with my friends is my daily routine after } \\
\text { class. }\end{array}$ & 3.14 & 0.84 & Sometimes Practiced \\
$\begin{array}{l}\text { 3. Watching television and playing on the internet café are my } \\
\text { hobbies after school. }\end{array}$ & 3.43 & 1.38 & Sometimes Practiced \\
$\begin{array}{l}\text { 4. Homework in Mathematics is interesting and mind-boggling. } \\
\text { 5. Studying Mathematics as well as doing Mathematics practice }\end{array}$ & 3.4 & 1 & Sometimes Practiced \\
drills during vacant times is my option. & 0.95 & Sometimes Practiced \\
$\begin{array}{l}\text { 6. Clarifying vague concepts about the lesson from my } \\
\text { classmate is an option to me. }\end{array}$ & 3.1 & 0.89 & Sometimes Practiced \\
$\begin{array}{l}\text { 7. I attend group studies related to Mathematics. } \\
\begin{array}{l}\text { 8. I do my homework because I do get support and assistance } \\
\text { from home. }\end{array}\end{array}$ & 3.24 & 1.28 & Sometimes Practiced \\
$\begin{array}{l}\text { 9. If there are confusing ideas or lesson in Mathematics, I ask } \\
\text { for help. }\end{array}$ & 3.52 & 1.26 & Sometimes Practiced \\
$\begin{array}{l}\text { 10.I spend time doing my homework/assignment in } \\
\text { Mathematics. }\end{array}$ & 3.48 & 1.2 & Often Practiced \\
\hline Overall & $\mathbf{3 . 2 7}$ & $\mathbf{1 . 1 1}$ & Sometimes Practiced \\
\hline
\end{tabular}

\section{Appendix B}

\section{Perceived Social Learning - Related Variables as to Attitude}

\begin{tabular}{|c|c|c|c|}
\hline Indicators & M & SD & Interpretation \\
\hline $\begin{array}{l}\text { 1. I enjoy doing task in Mathematics with or without } \\
\text { the instruction of the teacher. }\end{array}$ & 3.29 & 1.15 & Sometimes True To Me \\
\hline 2. I am excited to receive incentive for the good work & & & \\
\hline $\begin{array}{l}\text { I have done in Mathematics. } \\
\text { 3. I obey the rules and regulations set by my }\end{array}$ & 3.5 & 1.05 & Often True To Me \\
\hline Mathematics teacher. & 3.8 & 1.14 & Often True To Me \\
\hline $\begin{array}{l}\text { 4. I interact with my classmates with proper tone and } \\
\text { volume. }\end{array}$ & 3.4 & 1.03 & Often True To Me \\
\hline 5. I feel confident every time I attend my & & & \\
\hline $\begin{array}{l}\text { Mathematics class. } \\
\text { 6. I accept suggestions and criticisms when my }\end{array}$ & 3.71 & 1.01 & Often True To Me \\
\hline $\begin{array}{l}\text { answer/s is/are wrong. } \\
\text { 7. I respect my classmates/teachers/others. }\end{array}$ & $\begin{array}{l}3.8 \\
4.6\end{array}$ & $\begin{array}{l}\mathbf{1 . 1} \\
0.8\end{array}$ & $\begin{array}{l}\text { Often True To Me } \\
\text { Very True To Me }\end{array}$ \\
\hline $\begin{array}{l}\text { 8. I perform Mathematics exercises on my own or } \\
\text { with a friend. }\end{array}$ & 3.3 & 1.07 & Sometimes True To Me \\
\hline $\begin{array}{l}\text { 9. I feel excited and anxious during Mathematics } \\
\text { examinations. }\end{array}$ & 3.37 & 0.98 & Sometimes True To Me \\
\hline $\begin{array}{l}\text { 10. I am well-provided with Mathematics textbooks } \\
\text { and other learning resources in school and at home. }\end{array}$ & 3.2 & 1.02 & Sometimes True To Me \\
\hline Overall & 3.65 & 1.06 & Often True To Me \\
\hline
\end{tabular}

\section{Appendix C}




\section{Perceived Social Learning-Related Variables as to Interest}

\begin{tabular}{|c|c|c|c|}
\hline Indicators & $\mathbf{M}$ & SD & Interpretation \\
\hline 1. Numbers appeal to me the least. & 3.32 & 1.14 & Sometimes True To Me \\
\hline 2. Polynomial is alien to me. & 2.64 & 1.47 & Sometimes True To Me \\
\hline 3. Symbols give me headache. & 2.87 & 1.12 & Sometimes True To Me \\
\hline $\begin{array}{l}\text { 4. Working on Mathematics homework is stressful for me. } \\
\text { 5. Limited time pressures me which resulted to poor } \\
\text { comprehension. }\end{array}$ & 2.8 & 1.26 & Sometimes True To Me \\
\hline $\begin{array}{l}\text { 6. Any Mathematics book does not interest me. } \\
\text { 7. Limited knowledge in Mathematics is a hindrance in finding a }\end{array}$ & 2.44 & 1.24 & Sometimes True To Me \\
\hline $\begin{array}{l}\text { job. } \\
\text { 8. Homework will always be left undone if I do not know how to } \\
\text { do it. }\end{array}$ & 3.24 & 1.21 & Sometimes True To Me \\
\hline $\begin{array}{l}\text { 9. Nothing can force me to answer Mathematics questions. } \\
\text { 10. Calculator application is complicated and I will never get used }\end{array}$ & 2.86 & 1.17 & Sometimes True To Me \\
\hline to it. & 2.7 & 1.21 & Sometimes True To Me \\
\hline Overall & 2.88 & 1.21 & Sometimes True To Me \\
\hline
\end{tabular}

\section{Appendix D}

\section{Perception of the Respondents in Motivation in terms of Parental Guidance}

\begin{tabular}{lccll}
\hline \multicolumn{1}{c}{ Indicators } & M & SD & Interpretation \\
\hline My Parents... & & & & \\
1. are supportive in my studies. & 4.4 & 0.78 & Strongly Agree \\
2. help me in my assignments. & 3.26 & 1.11 & Moderately Agree \\
3. explain to me the importance of education. & 4.21 & 0.98 & Strongly Agree \\
4. prepare and save for my studies. & 3.98 & 1.07 & Agree \\
5. and siblings encourage me to learn. & 3.82 & 1.13 & Agree \\
6. keep motivating me to study well. & 4.03 & 1.04 & Agree \\
7. cannot afford to support my studies. & 2.55 & 1.34 & Disagree \\
8. are aware of my ability in Mathematics. & 3.56 & 1.15 & Agree \\
9. regularly attend school conferences to monitor my studies. & 3.39 & 1.14 & Moderately Agree \\
10. regularly browse my notes to check whether I am doing my & 3.28 & 1.21 & Moderately Agree \\
assignments. & $\mathbf{3 . 6 4}$ & $\mathbf{1 . 1}$ & \multicolumn{2}{c}{ Agree } \\
\hline \multicolumn{1}{c}{ Overall } & & & \\
\hline
\end{tabular}

\section{Appendix E}


Perception of the Respondents as to Motivation in terms of Peer Support

\begin{tabular}{lrrl}
\hline \multicolumn{1}{c}{ Indicators } & M & SD & Interpretation \\
\hline My friends... & & & \\
1. motivate me to study well. & 4.04 & 0.92 & Agree \\
2. help me in my assignments. & 3.54 & 1.07 Agree \\
3. are considerate while I'm studying. & 3.65 & 0.94 Agree \\
4. give me additional references. & 3.42 & 1.08 Agree \\
5. encourage me to learn. & 3.92 & 1.02 Agree \\
6. keep motivating me to study well. & 3.79 & 1.03 Agree \\
7. give me money to support my studies. & 2.15 & 1.36 Disagree \\
8. are aware of my ability in Mathematics. & 3.45 & 1.13 Agree \\
9. regularly visit me to play. & 2.9 & 1.28 Moderately Agree \\
10. inspire me in my studies. & 3.93 & 1.11 Agree \\
\hline \multicolumn{1}{c}{ Overall } & 3.48 & 1.09 & Agree \\
\hline
\end{tabular}

\section{Appendix F}

Perception of the Respondents as to Motivation in terms of Teacher Support

\begin{tabular}{lrrl}
\hline \multicolumn{1}{c}{ Indicators } & M & SD & Interpretation \\
\hline My teachers... & 4.5 & 0.8 & Strongly Agree \\
1. explain to me the importance of education. & 3.03 & 1.19 & Moderately Agree \\
2. help me in my assignments. & 4.01 & 0.96 & Agree \\
3. are supportive of my studies. & 4.13 & 0.95 & Agree \\
4. give me advice regarding Mathematics. & 4.13 & 1.07 & Agree \\
5. encourage me to learn. & 4.02 & 1.12 & Agree \\
6. keep motivating me to study well. & 2.03 & 1.22 & Disagree \\
7. give me money to support my studies. & 3.72 & 1.1 & Agree \\
8. are aware of my ability in Mathematics. & 3.74 & 1.19 & Agree \\
9. regularly monitor my progress in Mathematics. & & & \\
10. regularly browse my notes to check whether I am doing & 3.65 & 1.13 & Agree \\
my assignments. & $\mathbf{3 . 6 9}$ & $\mathbf{1 . 0 7}$ & Agree \\
\hline \multicolumn{1}{c}{ Overall } & &
\end{tabular}

\section{References}

Adeyinka, A. (2013). Teachers`Motivation on Students`Performance in Mathematics in Government Secondary Schools.

Ayob \& Yasin (2017). Factors Affecting Attitudes towards Mathematics. International Journal of Academic Research in Business and Social Sciences, Vol. 7, No. 11. DOI: Http://Dx.Doi.Org/10.6007/IJARBSS/V7-I11/3548

Bicer, A., Capraro, M. \& Capraro, R.M. (2013). The Effects of Parent's SES and Education Level on Students' Mathematics Achievement - Examining the Mediation Effects of Parental Expectation and Parental Communication. The Online Journal of New Horizons in Education (TOJNHE). 
Bitar, J. \& Zedan, R. (2014). Environment Learning as a Predictor of Mathematics Self - Efficacy and Math Achievement. American International Journal of Social Science.

Blazar, D., \& Kraft, M. (2017). Teacher and Teaching Effects on Students' Attitudes and Behaviors.

Brown, L. I. \& Kanyongo, G. (2010). Gender Differences in Mathematics Performance in Trinidad and Tobago: Examining Affective Factors.

Chand, Chaudhary, Prasad \& Chand. Perceived Causes Of Students' Poor Performance In Mathematics: A Case Study At Ba And Tavua Secondary Schools. Front. Appl. Math. Stat., 23 April 2021. Https://Doi.Org/10.3389/Fams.2021.614408

Cheng, Q. \& Hsu2, H. (2016). Low SES and High Mathematics Achievement: A Two-level Analysis of the Paradox in Six Asian Education Systems Journal of Education and Human Development.

Chohan A. (2010). Parental Involvement Effect on Academic Achievement of Primary School Pupils.

Cross et.al (2009). The Parents' Perspective and Beliefs: Impact On Children's' Outlook in Mathematics; Journal of Education and Practice; pp136-137

Davadas, S. D., \& Lay, Y. F. (2018). Factors Affecting Students' Attitude Toward Mathematics: A Structural Equation Modeling Approach. Eurasia Journal Of Mathematics, Science And Technology Education, 14(1), 517-529. Https://Doi.Org/10.12973/Ejmste/80356

Demir, Kilic, \& Unal (2010). Parental Involvement on Pupils' Performance in Mathematics in Public Schools in Austria.

Eccles \& Daviskean (2015). The Effects of Parent's Education Level on Students' Mathematics Achievement.

Fajoju, S. A., Aluede, O. \& Ojugo, A. (2015). Parental Involvement as a Correlate of Academic Achievement of Primary School Pupils in Edo State, Nigeria.

Fox, J \& Larke, P. (2014). Socio - economic status and Mathematics: A Critical Examination of Mathematics Performance in Grades 3 through 8.

Friedel et al. (2010). Effects of Parental Guidance in Mathematics Achievement and Performance of Students.

Gouc, G. (2013). Students Study Habit and Performance in Public and Private Secondary Schools Mathematics in Port Harcourt Local Government Area, Rivers State. Journal of International Academic Research of Multidisciplinary (JIARM).2(7), 258-265

Hannula, M. (2012). The Effect of Achievement, Gender, and Classroom Context on Upper Secondary Students' Mathematical Beliefs. University of Turku, Finland.

Heinze, A., Reiss, K., \& Augsburg, F. (2014). Mathematics Achievement and Interest in Mathematics from a Differential Perspective 
Herges, R.M., Duffield, S., Martin, W., Wageman, J. (2017). Motivation and Achievement of Middle School Mathematics Students.

Hernandez, G. (2014). Socio - Economic Status and Mathematics Achievement of Elementary Students in Public Schools.

Hong, You, and Wu (2010). A Survey of Students Study Habits in Selected Secondary Schools: Implication for Current Research Journal of Social Science, Vol. (3), 228-234.

Illiyas, M. (2017). Interest in Mathematics and Academic Achievement of High School Students in Chennai District.

Iruka \& Barbain (2008). Effectiveness of Parenting Strategies On Pupils' Achievement in Mathematics VIII.

Kolar ,Vida, Manfreda,et.al (2012). Primary Teacher Students' Competences in Inductive Reasoning: In Bergqvist, T (Ed) Learning Problem Solving and Learning Through Problem Solving.

Lubienzki, S. (2016). Current Rresearch on Gender Differences in Mathematics.

Makondo \& Makondo (2020). Causes Of Poor Academic Performance In Mathematics At Ordinary Level: A Case Of Mavuzani High School, Zimbabwe. International Journal of Humanities and Social Science Invention, Volume 9, Issue 6, pp. 10 - 18. DOI: 10.35629/7722-0906011018

Mata, M., Monteiro, V. \& Peixoto, F. (2012). Attitudes towards Mathematics: Effects of Individual, Motivational, and Social Support Factors.

Michael, I. (2015). Factors Leading To Poor Performance In Mathematics Subject In Kibaha Secondary Schools. A Dissertation Submitted In Partial Fulfilment Of The Requirements For The Degree Of Master Of Education In Administration, Planning And Policy Studies (Med. Apps) Of The Open University Of Tanzania.

Mutai, C. C. (2016). Gender Differences in Mathematics Performance among Secondary School Students in Bureti sub-county, Kericho county, Kenya.

Nyabuto, N. (2014). Parental Involvement on Pupils' Performance in Mathematics in Public Primary Schools in Kenya.

Odiri, O. (2015). Relationship of Study Habits with Mathematics Achievement.

Ovute, M. (2012). Factors Affecting Mathematics Performance of Learners.

Qiang Cheng \& Hsien-Yuan Hsu (2016). Interest in Mathematics of High School Students in Shanghai District. 
Recber, S., Isiksal, M., \& Koc, Y. (2018). Investigating Self-Efficacy, Anxiety, Attitudes, and Mathematics Achievement Regarding Gender and School Type. Anales de Psicologia. Murcia, Spain.

Saileela, R. (2012). Environment Learning as a Predictor of Mathematics Self - Efficacy and Attitude towards Mathematics.

Sakirudeen and Sanni (2017). The Effects of Study Habits on Turkish Elementary Students' Mathematics Achievement and Attitude Towards Mathematics.

Sanchal \& Sharma (2017). Students' Attitudes Towards Learning Mathematics: Impact Of Teaching In A Sporting Context. Teachers And Curriculum, Volume 17, Issue 1.

Sekhar \& Karanam (2014). Barriers in Learning Mathematics in Rural Secondary; Stellenbosch University.

Sharma, G. (2016). Teacher Support as Determinant of Academic Achievement.

Small, M. (2015). Good Questions: Great Ways to Differentiate Mathematics Instruction. New York, NY: Teachers College Press.

Vardardottir, A. (2012). Peer Effects and Academic Achievement Regression Discontinuity Approach.

Visser, M. \& Feza, N. (2015). Home and School Resources as Predictors of Mathematics Performance in South Africa. South African Journal of Education.

Wang, Li, \& Li. (2014). Socio - Economic Status and Mathematics Achievement in China: A Review.

Watt, Robert. (2005). The Importance of Mental Calculation Skills: A Review of the Literature. Rochester Institute of Technology.

Yalcin, S. (2017). Determining the Relationships Between Selected Variables and Latent Classes in Students' PISA Achievement. International Journal of Research in Education and Science.

Yara, P. (2004). Students Attitude Towards Mathematics and Academic Achievement in some Selected Secondary Schools in Southwestern Nigeria. 